\title{
メタラキシル粒剂とシアゾファミド水和剂を用いた ホウレンソウベと病の体系防除
}

\author{
堀之内勇人・渡辺秀樹・浅野雄二**桑原圭司**・小枝俊仁*** \\ (岐皁県農業技術センター・*岐阜県中山間農業研究所・**岐阜県病害虫防除所・ \\ ***岐阜県西濃地域農業改良普及センター)
}

2004年以降, 日本各地のホウレンソウ産地でべと病菌 レース $1 〜 5$ （以下, R1-5 と略す）に対する抵抗性品 種においてべと病の発生が報告されている吕。そのた め, 薬剤の効果的な利用技術は必要不可欠な状況である。 ベと病防除については，薬剤を予防的に散布することで 高い防除効果が得られることが報告されていたが1)，葉 に薬斑が残る，防除適期を逃すと効果が低い等の問題が あった。また, 近年, 環境保全型農業が推進されるなかで, 薬剤の使用回数の低減が求められている。そこで，ホウ レンソウベと病に対して新たに登録されたメタラキシル 粒剂とシアゾファミド水和剂を用いて防除試験を行っ た。

\section{材料および方法}

試験 1 は, メタラキシル粒剂の土壌混和処理とシアゾ ファミド水和剂 3 回散布の防除効果, メタラキシル粒剂 とシアゾファミド水和剂 1 回散布の体系処理の防除効果 を調べるために，2008年 1 月から 3 月に農業技術セン ター内のガラス温室で行った。メタラキシル粒剤は, 9 $\mathrm{kg} / 10 \mathrm{a}$ の使用量で農薬登録されているが，コスト低減 を目的に $6 \mathrm{~kg} / 10 \mathrm{a}$ 処理についても検討した。ホウレン ソウ品種は「アスパイアー (R1-5 抵抗性品種)」を用い, 試験面積及び反復は $0.75 \mathrm{~m}^{2}$ の 3 反復で行った。メタラ

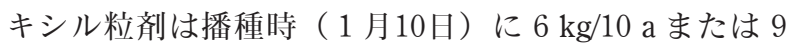
$\mathrm{kg} / 10 \mathrm{a}$ 相当量を土壤混和処理した。シアゾファミド水 和剂は2,000倍希釈液を播種34日，41日，48日後にバッ テリー式背負い噴霧器で $250 \mathrm{~L} / 10$ a 相当量を散布した。 体系処理は，播種時にメタラキシル粒剂（6 kg/10 a）を 土㙥混和処理した後, シアゾファミド水和剤 $(2,000$ 倍 希釈液）を播種34日, 41日または48日後に 1 回散布した。 ベと病菌（2007年に岐阜県飛騨市，品種スクープから採
取）は, 播種13日後（本葉 2 葉展開時）に約 $10^{5}$ spores/ $\mathrm{ml}$ の濃度に調整した胞子懸濁液をそれぞれの試験区の 一部に噴霧接種した。その後, べと病の発病を継時的に 調査し, 播種55日後（3 月 5 日）に発病株率及び発病葉 率を調査した。調査株数は反復あたり 60 株とした。

試験 2 は, メタラキシル粒剂（処理量 $6 \mathrm{~kg} / 10 \mathrm{a}$ ), シ アゾファミド水和剂の 1 回散布の防除効果を調べるとと もに再度, メタラキシル粒剤とシアゾファミド水和剂 1 回散布の体系処理による防除効果を調べた。試験は, 2008年 3 月から 4 月にガラス温室内で行った。ホウレン ソウ品種は「アスパイアー（R1-5 抵抗性品種）」を用い, 試験面積及び反復は $1 \mathrm{~m}^{2}$ の 2 反復で行った。メタラキ シル粒剂は $6 \mathrm{~kg} / 10 \mathrm{a}$ 相当量を播種時（3 月 12 日）に土

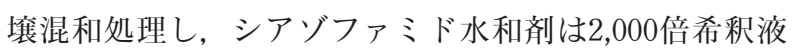
を播種22日，33日後に散布した。べと病菌は播種14日後 （本葉 2 葉展開時）に試験 1 と同様に接種した。べと病 の発病は, 播種44日後（4 月25日）に発病株率及び発病 葉率を調査した。調査株数は反復あたり60株とした。

\section{結果および考察}

試験 1 において, べと病の発病は播種40日後から急 速に進展し（第 1 図）, 播種55日後には無処理区で発病 株率 $89.4 \%$, 発病葉率 $48.1 \%$ であった（第 1 表)。メタ ラキシル粒剤の $9 \mathrm{~kg} / 10 \mathrm{a}$ 及び $6 \mathrm{~kg} / 10 \mathrm{a}$ 処理区のべと病 の発病は播種47日後から急速に進展し, 播種55日後の発 病株率はそれぞれ $58.3 \%, 78.9 \%$ ，発病葉率はそれぞれ 17.5\%（防除価63.6)，25.5\%（防除価48.0）であった。 シアゾファミド水和剂は 3 回散布することで, 発病株率 $23.9 \%$, 発病葉率5.2\%（防除価89.2）と高い防除効果が 得られ，散布による薬斑も見られなかった。メタラキシ ル粒剂を処理した後にシアゾファミド水和剂を 1 回散布

Hayato Horinouchi, Hideki Watanabe, Yuji Asano*, Keiji Kuwabara** and Toshihiro Saeda*** (Gifu Pref. Agr. Tech. Ctr., *Gifu Pref. Res. Inst. Agr. Tech. in Hill and Mountainous Area, ${ }^{* *}$ Gifu Plt. Prot. Office, ${ }^{* * *}$ Gifu Pref. Seino Agr. Devl. Ctr.): Control of downy mildew of spinach by combination of metalaxyl granure and cyazofamid wettable powder 2010年 2 月 15 日受理 


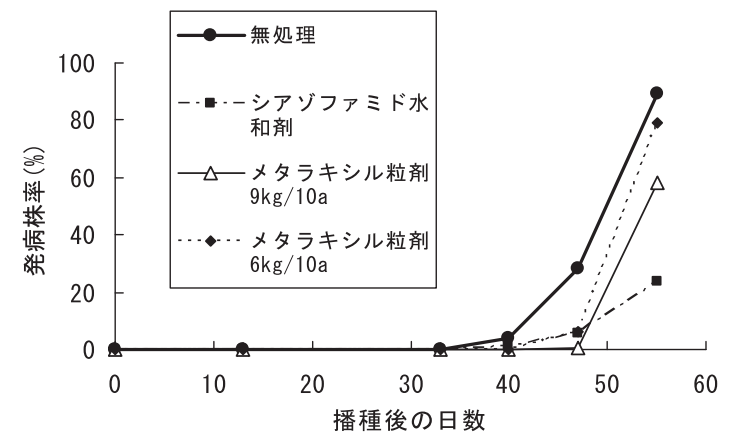

第 1 図 メタラキシル粒剂及びシアゾファミド水和剂の単用処 理区でのホウレンソウベと病の発病推移（試験 1 ) 注）べと病菌は播種13日後に接種

する体系防除は，シアゾファミド水和剂を播種34日後に 散布した区では発病株率13.3\%，発病葉率2.2\%（防除価 95.4）と, シアゾファミド水和剂 3 回散布区と比較して 高い防除効果が得られた。

試験 2 では, 試験期間が播種後44日とやや短いこと, 試験期間中の温室内の平均気温が $17.3^{\circ} \mathrm{C}$ （試験 1 の温室 内の平均気温は $\left.13.9^{\circ} \mathrm{C}\right)$ とやや高いことから, 無処理
区でのべと病の発病は発病株率89.4\%, 発病葉率 $22.3 \%$ であった（第 2 表）。その中で, シアゾファミド水和 剂を播種22日後に 1 回散布した区とメタラキシル粒剂 （6 kg/10 a）を処理した区は，それぞれ発病株率23.9\%, $25.0 \%$, 発病葉率2.5\%（防除価88.8), 3.1\%（防除価 86.1）と高い防除効果を示した。しかし，シアゾファミ ド水和剂を播種33日後に 1 回散布した区では発病株率 $58.3 \%$, 発病葉率 $14.0 \%$ (防除価37.2) と防除効果は低かっ た。メタラキシル粒剂を処理した後にシアゾファミド水 和剂を播種22日後に 1 回, 播種33日後に 1 回散布した体 系防除区は，それぞれ発病株率13.3\%，9.2\%，発病葉率 0.9\%（防除価96.0), 1.0\%（防除価95.5）と顕著に高い 防除効果を示した。

以上のことから, 播種から収穫まで $44 \sim 55$ 日間栽培の ホウレンソウにおいて, 播種時にメタラキシル粒剂を処 理し, 播種30日前後にシアゾファミド水和剂を 1 回散布 する体系防除はホウレンソウベと病の防除に有効である と判断された。また，体系防除は，単剤による防除より 高い防除効果を示し, 化学農薬の散布 (3 回) 労力の軽減 と減農薬栽培推進の上からも有益であると考えられる。

第 1 表 メタラキシル粒剤及びシアゾファミド水和剤の単用および組み合わせ処理によるホウレンソウベと病の防除効果（試験 1 )

\begin{tabular}{|c|c|c|c|}
\hline 処理区 & 発病株率（\%） & 発病葉率（\%） & 防除価 \\
\hline シアゾファミド水和剂 3 回散布 & 23.9 & 5.2 & 89.2 \\
\hline メタラキシル粒剤（9 kg/10 a） & 58.3 & 17.5 & 63.6 \\
\hline メタラキシル粒剂（6 kg/10a） & 78.9 & 25.0 & 48.0 \\
\hline メタラキシル粒剂＋シアゾファミド水和剂（播種34日後散布） & 13.3 & 2.2 & 95.4 \\
\hline メタラキシル粒剂＋シアゾファミド水和剂（播種41日後散布） & 36.1 & 6.4 & 86.7 \\
\hline メタラキシル粒剂＋シアゾファミド水和剤（播種48日後散布） & 69.4 & 20.9 & 56.5 \\
\hline 無処理 ～～～ & 89.4 & 48.1 & \\
\hline
\end{tabular}

注）播種55日後に調査

組み合わせ処理区のメタラキシル粒剂の処理量は $6 \mathrm{~kg} / 10 \mathrm{a}$

防除価は発病葉率から算出

第 2 表 メタラキシル粒剂及びシアゾファミド水和剤の単用および組み合わせ処理によるホウレンソウベと病の防除効果（試験 2 ）

\begin{tabular}{|c|c|c|c|}
\hline 処理区 & 発病株率（\%） & 発病葉率（\%） & 防除価 \\
\hline シアゾファミド水和剂（播種22日後散布） & 23.9 & 2.5 & 88.8 \\
\hline シアゾファミド水和剤（播種33日後散布） & 58.3 & 14.0 & 37.2 \\
\hline メタラキシル粒剤（6 kg/10 a） & 25.0 & 3.1 & 86.1 \\
\hline メタラキシル粒剂＋シアゾファミド水和剂（播種22日後散布） & 13.3 & 0.9 & 96.0 \\
\hline メタラキシル粒剤＋シアゾファミド水和剤（播種33日後散布） & 9.2 & 1.0 & 95.5 \\
\hline 無処理 & 89.4 & 22.3 & \\
\hline
\end{tabular}

注）播種44日後に調査

メタラキシル粒剤は播種時に $6 \mathrm{~kg} / 10 \mathrm{a}$ を土袞混和

シアゾファミド水和剤はそれぞれ 1 回のみ散布

防除価は発病葉率から算出 
今回, 薬㘊のコスト低減のために体系防除で用いたメ タラキシル粒剂の処理量は $6 \mathrm{~kg} / 10 \mathrm{a}$ としたが, 登録の 通りの処理量（9 kg/10 a）を用いた場合は, さらにより 安定して高い防除効果が得られることが期待できる。な お，本試験はガラス温室で試験を行ったことから降雨の 影響が無く, 薬剤の防除効果が高くなったと考元られる。 今後は, 露地栽培においても同様の防除効果が示される かを検討する必要がある。

\section{引用文献}

1）嶋埼 豊 (1988) 植物防疫 $42: 347-350$.

2）棚橋一雄 - 堀之内勇人 - 深井雅已 - 魚住雅信 - 浅野雄二 （2007）関西病虫研報 $49: 105$.（講要）

3）上山 博 - 片岡光信 - 福西 努（2008）関西病虫研報 50 : 194. (講要) 